\title{
Ideological Moderates Won't Run: \\ How Party Fit Matters for Partisan Polarization in Congress ${ }^{1}$
}

\author{
Danielle M. Thomsen \\ danielle.thomsen@duke.edu \\ Department of Political Science \\ Duke University \\ 407 Old Chemistry \\ Durham, NC 27708
}

\begin{abstract}
${ }^{1}$ Support for this research was provided by National Science Foundation grant SES-1263767 and the American Association of University Women. I am grateful to Peter Enns for his advice at multiple stages of this project. I also thank John Aldrich, Steve Coate, Jack Collens, Bryce Corrigan, Jason Hecht, Mary Katzenstein, Suzanne Mettler, Dave Rohde, Shauna Shames, and Chris Way for their helpful comments and suggestions. Previous versions of this article were presented at the annual meetings of the Southern Political Science Association and the Midwest Political Science Association, the Han-Jyun Hou Conference at Binghamton University, and seminars at Duke University and Cornell University, where I received valuable feedback. An online appendix with supplementary material for this article will be made available at the Journal of Politics website. All data and materials necessary to reproduce the results will be made available on publication at http://thedata.harvard.edu/dvn/dv/thomsen.
\end{abstract}




\begin{abstract}
Scholars have focused on elite-level and mass-level changes to explain partisan polarization in Congress. This article offers a candidate entry explanation for the persistence of polarization and the rise in asymmetric polarization. The central claim is that ideological conformity with the party — what I call Party Fit — influences the decision to run for office, and I suggest that partisan polarization in Congress has discouraged ideological moderates in the pipeline from pursuing a congressional career. I test this hypothesis with a survey of state legislators and with ideology estimates of state legislators who did and did not run for Congress from 2000 to 2010 . I find that liberal Republican and conservative Democratic state legislators are less likely to run for Congress than those at the ideological poles, though this disparity is especially pronounced among Republicans. The findings provide an additional explanation for recent patterns of polarization in Congress.
\end{abstract}

Keywords: Partisan Polarization, U.S. Congress, Party Fit, Candidate Emergence 
Partisan polarization has been one of the most prominent topics in congressional scholarship over the past decade. The distance between the two parties in Congress has continued to grow with nearly each election cycle, and partisan polarization is now at record highs (Poole and Rosenthal 2007). Those in the ideological middle have all but vanished from office, and Congress is currently characterized by what Bafumi and Herron (2010) call "leapfrog representation," with ideological extremists being replaced by other extremists. While it is clear that both parties have moved away from the center, scholars have also argued that polarization is "asymmetric" and that the Republican Party has shifted further to the right than the Democratic Party has to the left (e.g., Carmines 2011; Hacker and Pierson 2005; Mann and Ornstein 2012; McCarty et al. 2006; Skocpol and Williamson 2012). Studies of member ideology show that replacement processes are the primary driver behind the rise in polarization (Fleisher and Bond 2004; Theriault 2006) and asymmetric polarization (Carmines 2011), but we know little about why these replacements are more extreme than their predecessors.

This article contributes to the polarization literature by offering a candidate entry explanation that highlights ideological variation in the types of candidates who run for Congress. The central claim is that ideological conformity with the party's ideological reputation-what I call Party Fit - influences the decision to run for office. A party's ideological reputation conveys information about the type of candidate that belongs in the party, and potential candidates draw on this reputation to determine if they can achieve their electoral and policy goals and to decide whether to run for office. The Party Fit hypothesis suggests that in the contemporary political context, partisan polarization in Congress has discouraged ideological moderates in the political pipeline from pursuing a congressional career. I test this hypothesis with survey data of the perceptions of state legislators (Maestas et al. 2006; Stone et al. 2004) and with ideology 
estimates of state legislators who did and did not run for Congress from 2000 to 2010 (Bonica 2013b). I find that liberal Republican and conservative Democratic state legislators are less likely to run for Congress than those at the ideological poles, though this disparity is particularly pronounced on the Republican side. These findings provide an additional explanation for recent patterns of polarization in Congress, and they have important implications for the persistence of polarization over the long run. If the only individuals willing to run for Congress emerge from the ideological extremes, it is doubtful that partisan polarization will fade anytime soon.

\section{The Decline of Moderates in the U.S. Congress}

Scholars have focused on two types of explanations for the rise in partisan polarization in Congress. One set of explanations highlights various ideological shifts in the electorate. First, Southern constituencies became less homogeneously conservative following the passage of the Voting Rights Act, which enfranchised many African American voters who supported the Democratic Party (Aldrich 2011; Rohde 1991). Both parties gradually lost their moderate factions, with conservative whites in the South abandoning the Democrats and liberals in the Northeast leaving the Republicans. In addition, the electoral bases of the two parties shifted from being diverse to more uniform (Fleisher and Bond 2004; Stonecash et al. 2003). Despite the dispute over mass polarization (Abramowitz 2010; Abramowitz and Saunders 2008; Fiorina et al. 2006), most agree that voters are better sorted along party lines and that they increasingly match their partisanship with their ideological preferences (Hetherington 2001; Levendusky 2009). Lastly, party activists have become increasingly extreme (Fiorina et al. 2006; Layman and Carsey 2002; Layman et al. 2010; Theriault 2008). Because activists participate in 
primaries, contribute money to candidates, and spend their time working on campaigns, they have a greater impact on the electoral process than ordinary voters.

The other set of explanations for polarization instead highlights changes that have occurred within Congress. Increased levels of party homogeneity have supplied the leadership with tools to foster party discipline and advance the party's agenda (Aldrich 2011; Aldrich and Rohde 2001; Rohde 1991). Newly empowered party leaders have assumed greater responsibility in allocating committee assignments, setting the legislative agenda, and structuring debate on the floor (Cox and McCubbins 2005; Sinclair 2006). Majority party leaders draw extensively on legislative procedure to exert their will, and the resulting polarization on procedural issues has exacerbated the disparity between the two parties (Sinclair 2006; Theriault 2008). Moreover, party leaders are more extreme than the median member of the party caucus (Grofman et al. 2002; Heberlig et al. 2006; Jessee and Malhotra 2011), and they may move the party's agenda closer to their own preferences (Cox and McCubbins 1993; Roberts and Smith 2003).

As noted above, although both parties have shifted away from the center, a number of scholars have argued that there are key distinctions between the two parties (e.g., Carmines 2011; Hacker and Pierson 2005; Mann and Ornstein 2012; McCarty et al. 2006; Skocpol and Williamson 2012). They suggest that the Republican Party has moved further to the right than the Democrat Party has to the left (but see Bonica 2013b). Also, and particularly significant here, the Democratic delegation has remained relatively more ideologically dispersed (Bonica 2013a). Bonica's (2013b) CFscores show that in the $112^{\text {th }}$ Congress (2011-12), the standard deviation for the Democratic Party was 0.33, compared to 0.24 for Republicans. ${ }^{2}$ The moderate "Blue Dog" Democrats have retained an organized presence in Congress, while the Republicans

\footnotetext{
${ }^{2}$ The data are discussed in detail below. For now, it is sufficient to note that the congressional CFscores range from approximately -1.5 to 1.5 , with higher values indicating more conservative ideologies.
} 
have all but lost their moderate faction. Between 10 and 20 percent of Republican representatives belonged to the GOP's right-wing caucus in the 1980 s, but nearly $70 \%$ of Republicans in the current Congress are members (Mann and Ornstein 2012).

Like the general polarization literature, explanations for asymmetric polarization have focused on changes in party activists and the heightened use of restrictive procedures in Congress. Yet we are still searching for reasons as to why Congress is becoming more and more polarized with almost each election cycle. There is little empirical evidence to support the claim that gerrymandering and primary election systems have had a substantial effect on congressional polarization (Hirano et al. 2010; McCarty et al. 2009; McGhee et al. 2013; see also Sides and Vavreck 2013). And Fiorina et al. (2006) further illustrate how extremist voters, or at least sorted ones, can elect moderate candidates if these candidates are positioned at the ideological center. More generally, we know that member replacement is responsible for much of the rise in partisan polarization (Fleisher and Bond 2004; Theriault 2006) and asymmetric polarization (Carmines 2011), and scholars must begin to explore how candidate self-selection processes also contribute to these trends.

\section{A Party Fit Explanation for Polarization in Congress}

This article extends our understanding of contemporary patterns of partisan polarization in Congress by introducing the concept of Party Fit. Party Fit is the congruence between a candidate's ideology and the ideological reputation of the party delegation to which she would belong upon election. The party's ideological reputation is about "what the party stands for-and acts on-in terms of policy" (Aldrich and Freeze 2011, 186), and it gives meaning to its label and distinguishes the party from its opponent (Grynaviski 2010; Snyder and Ting 2002; Sniderman 
and Stiglitz 2012). While a party's ideological reputation matters in clear ways for the kinds of policies it pursues, scholars have paid less attention to how this reputation matters for the inclusion and exclusion of political candidates in the electoral process.

The central hypothesis is that ideological conformity with the party's reputation—what I call Party Fit—influences the decision to run for office. There are two mechanisms by which Party Fit affects the types of candidates who seek elective office: self-selection and party recruitment (Aldrich 2011). Candidates will self-select into electoral contests if they believe they are a good fit for the party, and those who do not will instead abstain. Similarly, party leaders will recruit candidates they deem electorally viable and gate-keep those they do not (Sanbonmatsu 2006). It is difficult to distinguish between these two mechanisms, and indeed, they are almost certainly mutually reinforcing. Due to the continued prominence of the candidate-centered model in American politics (Jacobson 2004; McGhee and Pearson 2011), this article focuses on the self-selection mechanism. However, the argument does not preclude a role for parties, and it is likely that party recruitment also shapes perceptions of Party Fit. In addition, the theoretical expectations apply to both incumbent and non-incumbent candidates, but because replacement processes have been central to the rise in polarization, I focus on the latter, and more specifically, on non-incumbents who are well situated to run for Congress.

There are many reasons to expect that potential candidates rely on the party's reputation to determine if they can achieve their electoral and policy goals (Fenno 1973; Mayhew 1974). ${ }^{3}$ First, potential candidates draw on this reputation to estimate their likelihood of winning. Sniderman and Stiglitz (2012) show that candidates receive a reputational premium if they take a

\footnotetext{
${ }^{3}$ Potential candidates can learn about the party's reputation through a variety of ways, such as polls, the media, and past candidates, but the ideological makeup of the party delegation is the best measure of the party's reputation. What is important is that this reputation provides different information than just knowing the ideology of the district.
} 
position that is consistent with the policy outlook of their party, and those who are positioned to run for office use the party's reputation to evaluate their own chance of winning. Second, potential candidates rely on the party's reputation to assess their future policy impact and their prospective influence in the legislative chamber (Fenno 1973). Members of Congress experience intense pressure to support the party's legislative agenda, and those who defect can expect to be punished for their actions and denied party rewards (Sinclair 2006; Theriault 2008).

The ability to achieve these electoral and policy goals has long been shown to matter in studies of political ambition (Black 1972; Rohde 1979; Schlesinger 1966), and Maestas et al. (2006) find that state legislators' perceived chance of winning and their reported value of a House seat are two of the most important predictors of their attraction to a congressional career. It is therefore crucial that we have a better understanding of what shapes these predictor variables. The Party Fit hypothesis suggests that ideological conformity with the party's reputation influences potential candidates' ability to achieve their electoral and policy goals, and those with preferences that conform to the party's reputation are more likely to run for political office than those with preferences that differ from this reputation. ${ }^{4}$

Because the party's ideological reputation changes over time and across historical contexts, the type of candidate that is a good fit for the party undergoes similar transformations. As I discuss below, I treat initial shifts in the party's reputation as exogenous. Over the past fifty years, the two parties have become increasingly homogeneous as well as more polarized, and partisan polarization in the U.S. House has now reached a record high (e.g., McCarty et al. 2006; Poole and Rosenthal 2007). There has been a hollowing out of the political center, and those in

\footnotetext{
${ }^{4}$ Snyder and Ting (2002) show formally that joining a party is less appealing to politicians whose preferences are distant from the party platform and more appealing to those with preferences that are similar to the platform. Like them, I also assume that these preferences are exogenous.
} 
the middle have either been defeated or chosen to leave. Ideological moderates in the congressional pipeline may assume that their candidacies are doomed from the start (Brady, Han, and Pope 2007) and that they would be unlikely to achieve their non-electoral goals if elected to office. Party leaders who set the legislative agenda are now ideologues themselves (Heberlig et al. 2006; Jessee and Malhotra 2011), and it would be difficult for moderates to either advance their desired policies or obtain a leadership position in Congress.

Thus, the Party Fit hypothesis suggests that in the contemporary context, ideological moderates in the congressional pipeline-liberal Republican and conservative Democratic state legislators-are less likely to run for Congress than those at the ideological poles. Specifically, the more liberal the Republican state legislator, the less likely she is to run for Congress; the more conservative the Democratic state legislator, the less likely she is to do so. The size of the effect may differ by party due to variation in the ideological heterogeneity of the two parties. The Democratic Party delegation has remained relatively more ideologically dispersed than the Republican delegation (Bonica 2013a). As a result, there will be fellow members for moderate Democrats to work with on policy issues, and the party may not seem as distant to moderate Democrats in the congressional pipeline.

It is similarly possible that potential candidates who are too extreme for the party may be dissuaded from running for Congress, but there are a variety of reasons to expect the congressional environment to be more attractive to ideologues than it is to moderates. For instance, ideologues are less likely to be cross-pressured than those in the middle, as their preferences are much closer to their party's position than that of the opposing party. Ideologues are also more likely to obtain a leadership position than members at the ideological center (Heberlig et al. 2006; Jessee and Malhotra 2011). Ideological extremity is therefore not expected 
to have a negative effect on the probability of running for Congress, although this pattern may emerge among state legislators who are extreme ideological outliers, such as those who are more extreme than the most conservative Republican and the most liberal Democratic members of Congress. Nevertheless, the main focus here is on ideological variation in the decision to run among potential congressional candidates who comprise the bulk of the candidate pool.

A final note is that it is important to be clear about what the Party Fit framework can and cannot explain. Because party reputations are taken as exogenous, it fails to account for why the parties polarized initially. Scholars have already highlighted the importance of ideological shifts in both the electorate and within Congress for the emergence of polarization. These changes moved the parties apart and clarified the party reputations for voters and potential candidates alike. The Party Fit argument does, however, provide an additional mechanism through which polarization in Congress has been reinforced and even exacerbated. Notably, these patterns can persist irrespective of ideological changes in the electorate.

\section{Data and Method}

State legislative office is a well-known springboard to Congress (Jacobson and Kernell 1983), and 51\% of those who served in Congress between 1999 and 2008 had prior state legislative experience (Carnes 2012). It is therefore ideal to test the Party Fit hypothesis on state legislators because they are well situated to run for Congress. ${ }^{5}$ I first draw on data from a national survey of state legislators conducted for the Candidate Emergence Study (Maestas et al. 2006; Stone and Maisel 2003; Stone et al. 2004). The CES data are unique in that they allow for an analysis of the perceptions of state legislators. The survey was mailed to state legislators

\footnotetext{
${ }^{5}$ Party Fit here is technically congressional party fit. More broadly, the theory refers to the party to which a candidate would belong upon election; I simply use Party Fit to capture the general concept.
} 
whose districts overlap with 200 randomly selected congressional districts in 41 states. There are a total of 569 state legislators, 262 Republicans and 307 Democrats, in the sample used here. ${ }^{6}$ Again, the Party Fit hypothesis suggests that ideological moderates in the pipeline-liberal Republican and conservative Democratic state legislators - are less likely to believe they can win the primary and less likely to value a seat in the U.S. House than those at the poles. The magnitude of the effect may differ by party due to variation in the ideological heterogeneity of the Republican and Democratic parties.

I use an OLS model to examine how Party Fit shapes state legislators' perceived chance of winning the primary and their value of a seat in the U.S. House. The dependent variables capture whether they believe they can achieve their electoral and non-electoral goals. ${ }^{7}$ The first dependent variable is a direct measure of state legislators' perceived chance of winning the primary. ${ }^{8}$ State legislators rated their chance of winning the party nomination if they ran for Congress in the foreseeable future. Following Maestas et al. (2006), the response is scaled as a "pseudo-probability" that ranges from 0.01 to 0.99 (extremely unlikely to extremely likely). The second dependent variable concerns the non-electoral goals that Fenno (1973) highlighted, measured as state legislators' value of a seat in the U.S. House. As in Maestas et al. (2006), the

\footnotetext{
${ }^{6}$ The data are drawn from the 1998 wave of the Candidate Emergence Study. The specific states are not identified in the publicly available data. The survey was mailed to 2,714 state legislators, and 874 of them responded, for a response rate of $32.2 \%$ (see Maestas et al. 2006, 199). Due to missing data, there are 597 respondents in the Maestas et al. (2006) study, compared to 569 used here; the decrease is because of the inclusion of ideology. I am not able to use the 2000 wave of the state legislator data, as ideology was not included in the survey. Maestas et al. (2006) also use only the 1998 wave in their study of state legislators.

${ }^{7}$ I follow the coding procedures used in the Maestas et al. (2006) study unless noted otherwise. All descriptive statistics are provided in Supplementary Appendix A.

${ }^{8}$ I also used "Chance of Winning the Primary and General Election," but I focus on the primary because candidates must first obtain support from primary voters. In addition, I used "Attraction to a House Career" as a dependent variable, but these better capture the electoral and non-electoral mechanisms that underlie political ambition.
} 
value of a House seat is measured in relative terms: state legislators rated the prestige and effectiveness of a career in Congress and their career in the state legislature, and the difference between these scores is the relative value of a seat in the House. Although this measurement might not exclusively capture policy impact and influence in the chamber, it is a good proxy for potential candidates' expected ability to achieve their non-electoral goals. The main independent variable of interest is the state legislator's self-reported ideology, which ranges from very liberal to very conservative. The variable is coded so that higher values correspond to Republican liberalism and Democratic conservatism. ${ }^{9}$

I control for several variables used by Maestas et al. (2006) in their study of political ambition, as the factors that shape attraction to a House career might also influence state legislators' perceived chance of winning the primary and their reported value of a House seat. State legislators who have been contacted by the party and those who believe they can raise money to fund their campaigns are expected to give higher evaluations of their perceived chance of winning and their value of a House seat. Respondents who are older as well as female state legislators may have more negative assessments of their chance of winning and report lower values of a House seat. State legislators with more support from outside groups and those who face strong incumbents are expected to be more and less likely, respectively, to believe they can achieve their goals. Not all of the controls are expected to have the same effect on both of the dependent variables, however. State legislators who perceive the district partisanship to be favorable may rate the value of the seat to be higher but assess their chance of winning to be

\footnotetext{
${ }^{9}$ I also ran the models with respondents' positions on four policy issues that are included in both of the party platforms. Respondents are coded as non-conformists if they are indifferent or oppose the position in their party's platform on an issue and conformists if they favor their party's position ( 1 and 0 , respectively). These values were summed across the policies; lower (higher) values indicate more (less) conformity with the party. The results are provided in Supplementary Appendix B.
} 
lower due to increased primary competition. Conversely, those who have served more terms in state legislative office and those in professionalized state legislatures may report a higher chance of winning but a lower seat value given the costs of leaving the state legislature.

\section{Results}

The results with the CES data are presented in Table 1 below. This section focuses on the main variable of interest, state legislator ideology, and then briefly reports the results on the control variables. The Republican model is discussed first and the Democratic model second. 
Table 1: The Determinants of State Legislators' Perceived Ability to Achieve their Electoral and Policy Goals, By Party

\begin{tabular}{|l|c|c|c|c|}
\hline & \multicolumn{2}{|c|}{$\begin{array}{c}c \mid \\
\text { State Legublican }\end{array}$} & \multicolumn{2}{c|}{$\begin{array}{c}\text { Democratic } \\
\text { State Legislators }\end{array}$} \\
\hline & $\begin{array}{c}\text { Chance of } \\
\text { Winning Primary }\end{array}$ & $\begin{array}{c}\text { Value of } \\
\text { House Seat }\end{array}$ & $\begin{array}{c}\text { Chance of } \\
\text { Winning Primary }\end{array}$ & $\begin{array}{c}\text { Value of } \\
\text { House Seat }\end{array}$ \\
\hline Self-Reported Ideology & $-0.04^{*}$ & $-0.44^{*}$ & -0.01 & 0.16 \\
(Republican Liberalism; & $(0.02)$ & $(0.18)$ & $(0.02)$ & $(0.20)$ \\
Democratic Conservatism) & & & & \\
\hline Favorable District & $-0.06 \dagger$ & -0.53 & $-0.07^{*}$ & 0.35 \\
Partisanship & $(0.04)$ & $(0.38)$ & $(0.03)$ & $(0.38)$ \\
\hline Ability to Raise Money & $0.05^{*}$ & -0.16 & 0.03 & $-0.43^{*}$ \\
& $(0.02)$ & $(0.21)$ & $(0.02)$ & $(0.20)$ \\
\hline Contacted by & $0.06^{* *}$ & 0.12 & $0.07^{* *}$ & -0.09 \\
Political Party & $(0.02)$ & $(0.19)$ & $(0.02)$ & $(0.19)$ \\
\hline Terms in State Legislative & -0.01 & -0.13 & -0.02 & -0.29 \\
Office & $(0.02)$ & $(0.19)$ & $(0.02)$ & $(0.20)$ \\
\hline In Professionalized State & $0.05^{* *}$ & -0.18 & $0.05^{* *}$ & -0.29 \\
Legislature & $(0.02)$ & $(0.19)$ & $0.02)$ & $(0.19)$ \\
\hline Incumbent Strength & -0.01 & $0.36 \dagger$ & $-0.05^{* *}$ & 0.23 \\
& $(0.02)$ & $(0.19)$ & $(0.02)$ & $(0.19)$ \\
\hline Support from & $0.06^{* *}$ & 0.10 & -0.01 & 0.28 \\
Outside Groups & $(0.02)$ & $(0.20)$ & $(0.02)$ & $(0.19)$ \\
\hline Female & 0.02 & -0.87 & -0.04 & -0.56 \\
& $(0.05)$ & $(0.53)$ & $(0.04)$ & $(0.44)$ \\
\hline Age & $-0.10^{* *}$ & 0.07 & $-0.10^{* *}$ & $0.37 \dagger$ \\
& $(0.02)$ & $(0.19)$ & $(0.02)$ & $(0.20)$ \\
\hline Constant & $0.53^{* *}$ & $0.50 \dagger$ & $0.57^{* *}$ & $-0.97^{* *}$ \\
& $(0.03)$ & $(0.30)$ & $(.03)$ & $(0.32)$ \\
\hline Number of Observations & 262 & 262 & 307 & 307 \\
\hline $\mathrm{R}^{2}$ & 0.31 & 0.07 & 0.28 & 0.06 \\
\hline
\end{tabular}

Source: 1998 Wave of the Candidate Emergence Study (Stone and Maisel 2003; Stone et al. 2004; Maestas et al. 2006). Note: Entries are OLS regression coefficients with standard errors in parentheses.

$* *=\mathrm{p}<0.01, *=\mathrm{p}<0.05, \dagger=\mathrm{p}<0.10$.

The key result in the Republican model is that liberal Republicans in the congressional pipeline are less likely to believe they can achieve their electoral and policy goals than those with more conservative preferences. ${ }^{10}$ First, liberal Republican state legislators perceive their chance

\footnotetext{
${ }^{10}$ The relationship between ideology and the two dependent variables is equally strong when the controls are omitted from the models, and the results remain the same when "Chance of Winning the Primary and
} 
of winning the primary to be lower, on average, than conservative Republicans. The size of this effect ranks highly in comparison to the control variables. ${ }^{11}$ A one-unit increase in Republican liberalism results in a four percentage point decline in their perceived chance of winning the primary. Similarly, a standard deviation increase in party recruitment and support from outside groups leads to a six percentage point rise in state legislators' expected chance of winning, and the effect of a one-unit increase in the ability to raise money and state legislative professionalization is five percentage points. In addition, a standard deviation increase in age and a shift from an unfavorable to a favorable district partisan balance leads to a ten and six percentage point decrease in their perceived chance of winning, respectively. ${ }^{12}$ Second, ideology is also a significant predictor of Republican state legislators' reported value of a congressional seat, with liberal Republicans assessing the relative value of a House seat to be lower than conservative Republicans. A standard deviation increase in being ideologically moderate results in nearly a half-point decline in state legislators' reported value of a congressional seat, or approximately $2.2 \%$ of the total range of the scale.

Among Democratic state legislators, the results suggest that conservatives and liberals are statistically indistinguishable in terms of their perceived chance of winning the primary and their reported value of a seat in the U.S. House. However, the lack of significance among Democrats

General" is the dependent variable. Also, the results are similar when policy preferences are used instead of ideology. Republican state legislators with preferences that do not conform to the party's platform are less likely to believe they can achieve their electoral and non-electoral goals than those with preferences that do (see Supplementary Appendix B).

${ }^{11}$ Predictor variables were standardized to have a mean of zero and a standard deviation of one.

${ }^{12}$ I am not able to test whether respondents self-select out of running or are gate-kept out by party leaders, but I expect both mechanisms to be at work. Among very conservative and conservative Republicans, $4.4 \%$ reported being contacted by the party, versus $1.8 \%$ of those with more liberal preferences, which conforms to the argument here. In terms of the model, this would lead me to underestimate the effect of ideology as candidate ideology might have an influence on party recruitment but not vice versa, as the ideology of most legislators does not change significantly over time (Poole and Rosenthal 2007). 
makes sense given the timing of the survey. This wave of the CES survey was conducted in 1998, and there were important ideological differences between the parties at that point. In the $105^{\text {th }}$ Congress (1997-98), the median House Republican had a CFscore of 0.80 and the median Democrat had a score of -0.65 , compared to 0.94 and -0.79 for the median Republican and Democrat, respectively, in the $112^{\text {th }}$ Congress (2011-12). Also, the standard deviation of the GOP in the $105^{\text {th }}$ Congress was 0.27 , whereas the Democratic Party had a standard deviation of 0.33. Conservative Democrats were thus a better fit for the party in the late 1990s, and furthermore, the party might not have seemed as distant because of the relative heterogeneity of the party caucus. The null results among Democratic state legislators are therefore not surprising given the ideological makeup of the Democratic Party at the time of the survey.

The results on the control variables are similar to those in the Republican models. ${ }^{13}$ State legislators who were contacted by the political party and those in more professionalized state legislatures believe they are more likely to win the primary. Also, Democratic state legislators rate their chance of victory to be lower when the incumbent is strong, and respondents who are older as well as those who deem the partisan balance of their districts to be favorable say they are less likely to win the primary. Those who are older also assess the value of a seat in the House to be lower $(\mathrm{p}<0.10)$, and contrary to expectations, the relationship between state legislators' ability to raise money and their reported value of a House seat is negative.

In sum, traditional factors such as party recruitment, past political experience, and the ability to garner support from voters, donors, and outside groups matter in clear ways for whether state legislators believe they can achieve their electoral and policy goals. However, scholars have overlooked how state legislators' ideological congruence_-or lack thereof_-with

\footnotetext{
${ }^{13}$ When the sample is not split along party lines, nearly all of the control variables conform to the expectations in the Data and Method section (see Supplementary Appendix C).
} 
their party's ideological reputation may also influence candidate emergence. The findings suggest that liberal Republicans in the pipeline are less likely to believe they can achieve their electoral and policy goals than conservatives in the pipeline. Conservative and liberal Democrats in the pipeline are statistically indistinguishable in terms of their perceived chance of winning the primary and their reported value of a House seat, but this makes sense given the ideological makeup of the Democratic Party at the time of the survey.

\section{The Implications of Party Fit for Candidate Emergence}

The CES data help to shed light on the perceptions of state legislators, but it would also be useful to analyze the ideological profile of state legislators who decide to run for Congress, as we are ultimately interested in how patterns of candidate self-selection contribute to partisan polarization. In addition, because the replacement of moderates has occurred gradually and over multiple election cycles, it would be ideal to test the Party Fit hypothesis with more recent data and data that span a longer time period. A new dataset created by Bonica (2013b) allows us to do both. Bonica (2013b) uses campaign finance records from state and federal elections to estimate the ideology of a wide range of political actors, including members of Congress, state legislators, interest groups, and individual donors. Most importantly here, the dataset includes ideal points for state legislators who did and did not run for Congress from 2000 to $2010 .{ }^{14}$ This

\footnotetext{
${ }^{14}$ The goal was to restrict the sample to "quality congressional candidates" who do and do not run for Congress (Jacobson and Kernell 1983). Thus, the sample includes state legislative incumbents who make their first run for Congress and state legislative incumbents who run for the state legislature again but could have run for Congress. The sample excludes first-time state legislative candidates who are not yet quality candidates, those who have previously run for the state legislature and lost, as well as state legislators who seek higher state legislative office. The sample also excludes state legislative incumbents who have previously run for Congress, as the aim is to compare the decision to run for Congress across similarly situated state legislators.
} 
enables a test of Party Fit specifically in the polarized context, as partisan polarization had become a defining characteristic of Congress during these years. ${ }^{15}$

First, though, it is possible that the pool of congressional candidates with state legislative backgrounds varies by party. If successful Republican candidates are less likely to have previous state legislative experience or if Republican candidates are more likely to be political amateurs, an analysis of state legislators may be less relevant for patterns of polarization in Congress. However, there is little evidence of such partisan differences either among the pool of successful candidates or the full pool of congressional candidates. The same proportions of Democrats and Republicans in Congress — successful candidates - have previous state legislative experience (50.9\% of Democrats and 51.5\% of Republicans) (Carnes 2012). Moreover, in the full pool of successful and unsuccessful non-incumbent candidates who ran for Congress from 2000 to 2010 (Bonica 2013b), 17\% of Republicans and 15\% of Democrats had state legislative backgrounds. This suggests that state legislators are an appropriate sample from which to assess the broader implications of Party Fit for changes in congressional polarization.

I use a logistic regression to estimate the relationship between state legislator ideology and her decision to run for Congress. The Republican model includes 14,459 observations and the Democratic model includes 16,571 observations. ${ }^{16}$ The dependent variable is coded 1 if the

\footnotetext{
${ }^{15}$ Bonica's state legislator estimates are available from 1990 to 2010, but I restrict the sample from 2000 to 2010. The number of state legislative candidates who filed with the FEC was significantly lower prior to 2000 , so the number of state legislators in the dataset who could have run for office was unreasonably low. Specifically, there are 8,027 observations in the dataset between 1990 and 1998, compared to 31,030 between 2000 and 2010. According to the National Conference of State Legislatures, there are 7,300 state legislators nationwide in a given election cycle, so the latter figure is a much closer approximation of the eligible pool of state legislators (NCSL 2013).

${ }^{16}$ The state legislators represent 49 states; Nebraska is excluded because its legislature is non-partisan. Of the pool of Republican state legislators who were well situated for Congress in a given election year from 2000 to 2010, $290(2.0 \%)$ ran for Congress and 14,169 did not. In the pool of Democratic state legislators, 208 (1.3\%) ran for Congress and 16,363 did not. I also ran a rare event logistic regression,
} 
state legislator runs for Congress in a given year and 0 if she runs for the state legislature again. The primary independent variable is the ideology of the state legislator, coded so that higher values correspond to Republican liberalism and Democratic conservatism. ${ }^{17}$ The Party Fit hypothesis suggests that Republican liberalism and Democratic conservatism have a negative effect on candidate emergence: the more liberal (conservative) the Republican (Democratic) state legislator, the less likely she is to run for Congress. Again, given that the Democratic Party has remained relatively more ideologically heterogeneous during this time, the magnitude of the effect may differ by party. ${ }^{18}$

The model includes controls for a variety of electoral, institutional, and partisan factors. To account for district-level factors, I control for whether there was an incumbent running for reelection in the state legislator's congressional district, as well as the ideology of the state legislator's congressional district (Tausanovitch and Warshaw 2013). ${ }^{19}$ I used Bonica's (2013b) data to calculate the average amount of money individuals raised as state legislators, as this

and the results are identical. In addition, I ran the model with state fixed effects, and the results remain the same. State fixed effects are not included here because doing so leads to a sizeable decrease in the number of observations, but year fixed effects are included.

${ }^{17}$ The state legislator ideology data are shown descriptively in Supplementary Appendix D. I also measured Party Fit as the difference between the state legislator's ideology and the congressional party median (i.e., the absolute distance between her CFscore and the CFscore of the party median) and as the state legislator's relative closeness to her party in Congress (i.e., the absolute value of a state legislator's distance from her party median subtracted from the absolute value of her distance from the opposing party median) (see Supplementary Appendix E). I use state legislator ideology here, as the main goal is to highlight how candidate self-selection matters for patterns of partisan polarization in Congress.

${ }^{18}$ While the theory also posits a role for the ideological heterogeneity of the party, the standard deviation of the CFscores of either party do not vary sufficiently during the time frame here to include them in the model.

${ }^{19}$ I used Census data to assign state legislative districts (SLD) to their corresponding congressional district (CD). For SLDs that fall into more than one CD, I used the CD in which their SLD comprised a larger portion of the $\mathrm{CD}$ population. The incumbency data were generously provided by Gary Jacobson. 
likely corresponds to their ability to fund a congressional campaign. I also control for the number of times individuals sought state legislative office and the gender of the state legislator. State legislative professionalization is measured with the Squire (2007) index, and I include measures of partisan control of the state legislature (Klarner 2013) and whether the state legislature has term limits. Lastly, I include a dummy variable for Republican (Democratic) state legislators who are more extreme than the most conservative Republican (liberal Democratic) member of Congress to account for ideological outliers.

The results are presented in Table 2 below. Of most importance is the negative coefficient on the Party Fit variable. ${ }^{20}$ As expected, Republican liberalism and Democratic conservatism has a negative effect on candidate emergence: the more liberal the Republican state legislator, the less likely she is to run for Congress; the more conservative the Democratic state legislator, the less likely she is to do so. ${ }^{21}$

\footnotetext{
${ }^{20}$ The models with the alternative specifications of Party Fit tell the same story: state legislators who are further from the congressional party median are less likely to run for Congress, and state legislators who are relatively closer to their own party median are more likely to do so (see Supplementary Appendix E).

${ }^{21}$ In the graphs shown here, the probability of running for Congress is highest among state legislators at the extremes, though this probability eventually decreases among very extreme ideologues. These graphs are provided in Supplementary Appendix F. The focus of this article is on the bulk of the observations in the dataset, but the fact that being too extreme is also a liability lends support to the Party Fit hypothesis.
} 
Table 2: The Determinants of Running for Congress, By Party (2000-2010)

\begin{tabular}{|l|c|c|}
\hline & $\begin{array}{c}\text { Republican } \\
\text { State Legislators }\end{array}$ & $\begin{array}{c}\text { Democratic } \\
\text { State Legislators }\end{array}$ \\
\hline State Legislator Ideology (Republican & $-2.94^{* *}$ & $-2.16^{* *}$ \\
Liberalism; Democratic Conservatism) & $(0.27)$ & $(0.23)$ \\
\hline Incumbent Running in & $-2.36^{* *}$ & $-2.37^{* *}$ \\
Congressional District & $(0.13)$ & $(0.17)$ \\
\hline Ideology of Congressional District & $-1.81^{* *}$ & 0.62 \\
(Higher=Conservative) & $(0.30)$ & $(0.33)$ \\
\hline Log of Mean Receipts & $0.47^{* *}$ & $0.54^{* *}$ \\
Raised as State Legislator & $(0.06)$ & $(0.07)$ \\
\hline Number of Times Run for & $0.34^{* *}$ & $0.30^{* *}$ \\
State Legislature & $(0.04)$ & $(0.05)$ \\
\hline Female & -0.14 & $-0.35^{*}$ \\
& $(0.17)$ & $(0.16)$ \\
\hline In Professionalized & $1.73^{* *}$ & 0.62 \\
State Legislature & $(0.58)$ & $(0.69)$ \\
\hline In State Legislature with & $0.76^{* *}$ & $0.89^{* *}$ \\
Term Limits & $(0.15)$ & $(0.18)$ \\
\hline Democratic Control of & $0.75^{* *}$ & -0.25 \\
State Legislature & $(0.17)$ & $(0.23)$ \\
\hline Extreme Ideologue & -0.37 & -0.51 \\
& $(1.20)$ & $(0.50)$ \\
\hline Constant & $-11.69^{* *}$ & $-11.42^{* *}$ \\
& $(0.81)$ & $(0.81)$ \\
\hline Number of Observations & 14,459 & 16,571 \\
\hline Log-Likelihood & -1119.02 & -871.67 \\
\hline S
\end{tabular}

Source: State legislator estimates are from Bonica (2013b).

Note: Entries are logistic regression coefficients with robust standard errors clustered by individual in parentheses. The dependent variable is coded 1 if the incumbent state legislator ran for Congress and 0 if the incumbent state legislator instead ran for the state legislature. ${ }^{* *}=\mathrm{p}<0.01,{ }^{*}=\mathrm{p}<0.05$.

Figure 1 presents the predicted probability of running for Congress for Republican state legislators across a range of ideology scores. ${ }^{22}$ The graph also shows the predicted probabilities for state legislators who have the same ideology scores as various former and current members of Congress, including moderates like Olympia Snowe (R-ME) and Steven LaTourette (R-OH) and conservatives like Paul Ryan (R-WI) and Speaker John Boehner (R-OH). The probability

${ }^{22}$ All other variables are set at their mean or mode. 
that any state legislator runs for Congress is low, but the difference across Republicans is striking. For state legislators who resemble conservatives like Paul Ryan and John Boehner, the probability of running for Congress is $1.9 \%$ and $1.1 \%$, respectively, but this decreases to $0.3 \%$ and $0.2 \%$ for state legislators who resemble ideological moderates like Steven LaTourette and Olympia Snowe, respectively. In other words, the probability that a conservative state legislator like Paul Ryan runs for Congress is more than nine times greater than that of a moderate state legislator like Olympia Snowe.

\section{Figure 1: Predicted Probability of Running for Congress for Republican State Legislators, By State Legislator Ideology (2000-2010)}

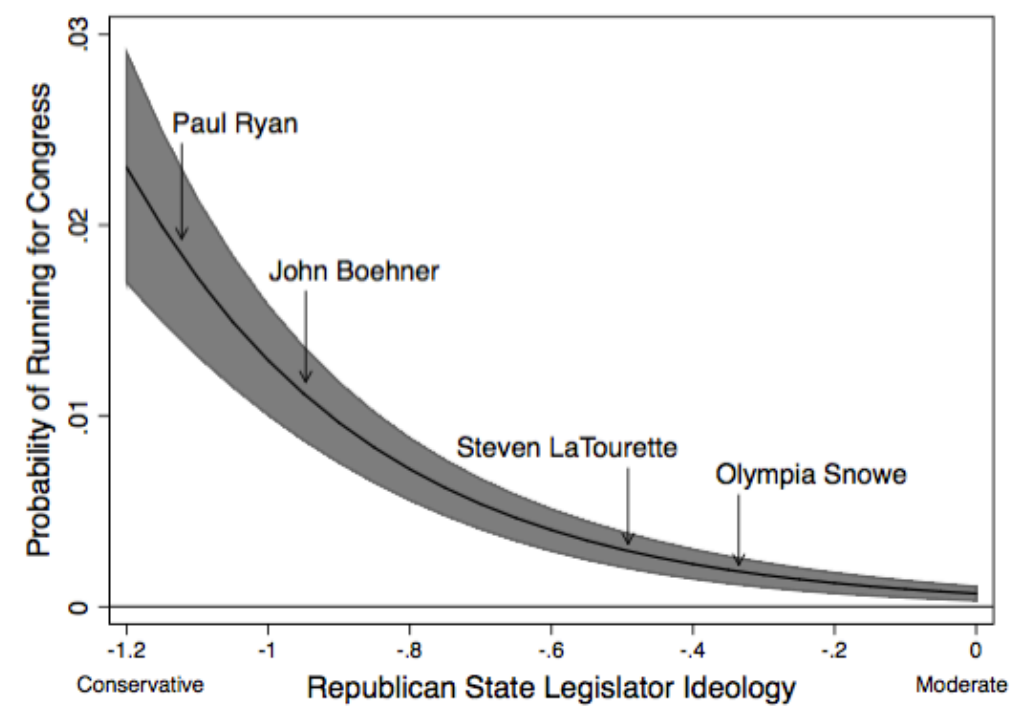

Note: The arrows refer to hypothetical state legislators that have the same ideological scores as various former and current members of Congress. For example, the arrow corresponding to Paul Ryan represents the probability of running for Congress for a state legislator who has the same ideology score as Ryan.

For Democratic state legislators, the situation looks slightly different. Conservative Democrats are also less likely to run for Congress than those with more liberal preferences, but there are important differences between Republicans and Democrats in terms of the size of the effect. Figure 2 illustrates the predicted probability of running for Congress for Democratic state 
legislators across a range of ideology scores. We can also use the scores of former and current Democratic members of Congress to calculate the probability of running for Congress for state legislators who resemble moderates like Marcy Kaptur (D-OH) and Bart Gordon (D-TN) or liberals like Nancy Pelosi (D-CA) and Mike Capuano (D-MA). In comparison to Republicans, the disparity across Democrats is small: the probability that liberal state legislators like Nancy Pelosi and Mike Capuano run for Congress is $1.1 \%$ and $0.7 \%$, respectively, versus $0.4 \%$ and $0.2 \%$ for a moderate state legislator who resembles Marcy Kaptur and Bart Gordon, respectively. These patterns conform to Carmines' (2011) finding that the ideological distribution of newly elected Democrats is wider than that of newly elected Republicans.

Figure 2: Predicted Probability of Running for Congress for Democratic State Legislators, By State Legislator Ideology (2000-2010)

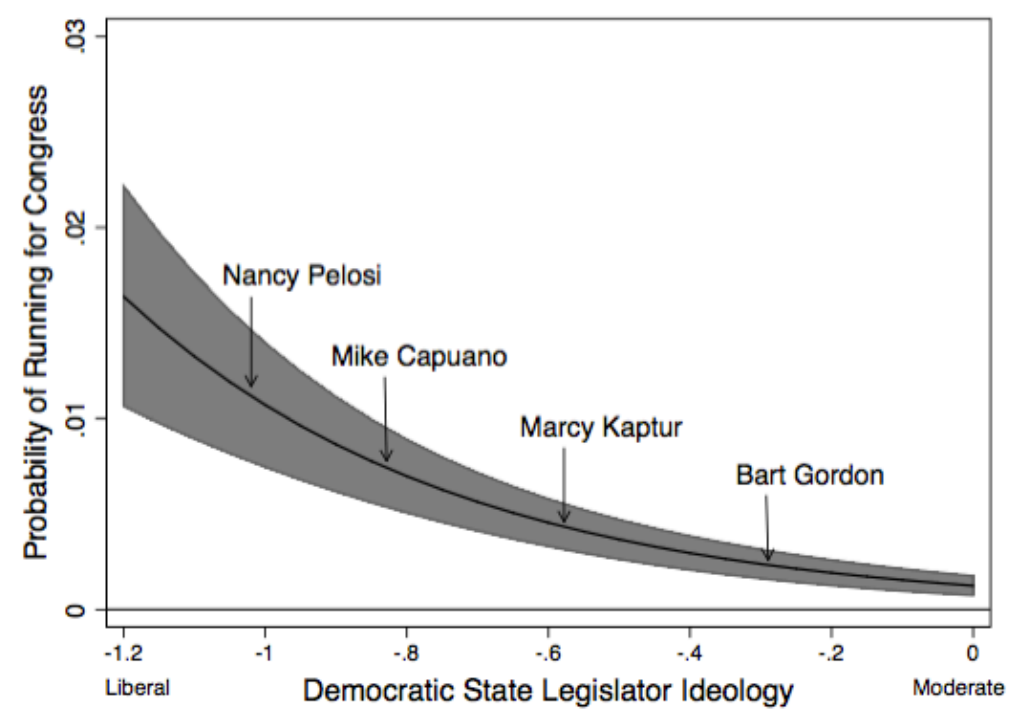

Note: The arrows refer to hypothetical state legislators that have the same ideological scores as various former and current members of Congress. For example, the arrow corresponding to Nancy Pelosi represents the probability of running for Congress for a state legislator who has the same ideology score as Pelosi. 
In terms of the control variables, the probability of seeking congressional office is lower for Republican and Democratic state legislators in districts with incumbents running for reelection. Republican state legislators that are nested in conservative congressional districts are less likely to run for Congress, whereas Democrats that are nested in conservative districts are more likely to do so $(\mathrm{p}<0.10)$. This conforms to the result above that state legislators who report a favorable district partisanship believe it would be more difficult to win the primary. Also, those who raised more money as state legislators and those with more experience as state legislative candidates are more likely to seek higher office, as well as state legislators who are term-limited. Republicans in professionalized state legislatures and state legislatures with higher levels of Democratic control are more inclined to run for Congress. Among Democrats, women are less likely to run for Congress than their male counterparts. Lastly, the coefficient on the extreme ideologue dummy variable is insignificant in both models, which may in part be due to the relative dearth of very extreme ideologues in the dataset. ${ }^{23}$

Taken together, the results provide evidence in support of the Party Fit hypothesis, which suggests that ideological moderates in the congressional pipeline are less likely to run for Congress than those at the ideological poles. Specifically, the more liberal the Republican state legislator, the less likely she is to run for Congress; the more conservative the Democratic state legislator, the less likely she is to do so. This disparity between ideologues and moderates is particularly pronounced on the Republican side, which provides an additional explanation for why Republican replacements have been increasingly conservative (Bonica 2010; Carmines 2011). While scholars have yet to explore the effect of candidate ideology and Party Fit on the

\footnotetext{
${ }^{23}$ The results are identical if the extreme ideologue dummy variable is excluded from the models.
} 
decision to run for congressional office, the results presented here show that patterns of candidate entry have important implications for the persistence of polarization in Congress.

\section{Conclusion}

Scholars of American politics have pointed to two main explanations for partisan polarization in Congress: mass-level changes in the electorate and institutional-level changes in Congress. This article builds on the literature by offering a candidate entry explanation for how polarization has been reinforced and even exacerbated. The Party Fit hypothesis suggests that ideological extremism in Congress has discouraged moderates in the congressional pipeline from running for Congress. I find that in the contemporary political context, liberal Republican and conservative Democratic state legislators are less likely to launch a congressional bid than those at the ideological poles. The results help to account for the absence of a new cohort of incoming moderate candidates, particularly on the Republican side (see Carmines 2011), and they have important implications for the persistence of polarization in Congress. Indeed, member replacement processes are the main driver behind the rise in polarization (Theriault 2006), and the abstention of ideological moderates from the candidate pool—and the selection of ideologues into the candidate pool—suggests that partisan polarization is here to stay.

Nearly fifty ago Schlesinger $(1966,1)$ claimed, "Ambition lies at the heart of politics." The quality of political representation is compromised when only a narrow ideological subset of individuals is willing to engage in electoral contests. Scholars of legislative representation and partisan polarization must turn their attention to questions of candidate emergence to understand why some individuals seek elective office and others do not. The democratic ideal deeply depends on, and indeed takes for granted, the existence of a vibrant and diverse pool of 
candidates from which voters can choose. If the only candidates who are willing to run for office are as extreme as the rascals in office, this has serious consequences for the representation of those in the ideological middle, which includes the majority of the American people. 


\section{References}

Abramowitz, Alan I. 2010. The Disappearing Center: Engaged Citizens, Polarization, and American Democracy. New Haven, CT: Yale University Press.

Abramowitz, Alan I. and Kyle L. Saunders. 2008. “Is Polarization a Myth?” Journal of Politics 70(2): 542-555.

Aldrich, John H. 2011. Why Parties? A Second Look. Chicago: University of Chicago Press.

Aldrich, John H. and Melanie Freeze. 2011. "Political Participation, Polarization, and Public Opinion: Activism and the Merging of Partisan and Ideological Polarization." In Facing the Challenge of Democracy: Explorations in the Analysis of Public Opinion and Political Participation, eds. Paul M. Sniderman and Benjamin Highton. Princeton, NJ: Princeton University Press.

Aldrich, John H. and David W. Rohde. 2001. "The Logic of Conditional Party Government: Revisiting the Electoral Connection." In Congress Reconsidered, eds. Lawrence Dodd and Bruce Oppenheimer. Washington, DC: CQ Press.

Ansolabehere, Stephen, James M. Snyder, Jr., and Charles Stewart III. 2001. "Candidate Positioning in U.S. House Elections." American Journal of Political Science 45(1): 136-159.

Bafumi, Joseph and Michael C. Herron. 2010. "Leapfrog Representation and Extremism: A Study of American Voters and Their Members in Congress." American Political Science Review 104(3): 519-542.

Black, Gordon S. 1972. "A Theory of Political Ambition: Career Choices and the Role of Structural Incentives.” American Political Science Review 66(1): 144-159.

Bonica, Adam. 2010. "Introducing the $112^{\text {th }}$ Congress." Ideological Cartography, November 5, 2012. http://ideologicalcartography.com/2010/11/05/introducing-the-112th-congress/.

Bonica, Adam. 2013a. "Interests and Ideology in the Political Marketplace." American Journal of Political Science 57(2): 294-311.

Bonica, Adam. 2013b. "Mapping the Ideological Marketplace." American Journal of Political Science doi: 10.1111/ajps.12062.

Brady, David W., Hahrie Han, and Jeremy C. Pope. 2007. "Primary Elections and Candidate Ideology: Out of Step with the Primary Electorate?" Legislative Studies Quarterly 32(1): 79-105.

Carmines, Edward G. 2011. "Review Symposium: Class Politics, American Style.” Perspectives on Politics 9(3): 645-647. 
Carnes, Nicholas. 2012. Congressional Leadership and Social Status (CLASS) Dataset, v. 1.9 [computer file]. Available from the author, nicholas.carnes@duke.edu.

Cox, Gary W. and Mathew D. McCubbins. 1993. Legislative Leviathan: Party Government in the House. Berkeley: University of California Press.

Cox, Gary W. and Mathew D. McCubbins. 2005. Setting the Agenda: Responsible Party Government in the U.S. House of Representatives. New York: Cambridge University Press.

Fenno, Richard F. 1973. Congressmen in Committees. Boston: Little, Brown.

Fiorina, Morris P., Samuel J. Abrams, and Jeremy C. Pope. 2006. Culture War? The Myth of a Polarized America. New York: Pearson/Longman.

Fleisher, Richard and John R. Bond. 2004. "The Shrinking Middle in the US Congress." British Journal of Political Science 34(3): 429-451.

Grofman, Bernard, William Koetzle, and Anthony J. McGann. 2002. "Congressional Leadership 1965-96: A New Look at the Extremism versus Centrality Debate.” Legislative Studies Quarterly 27(1): 87-105.

Grynaviski, Jeffrey D. 2010. Partisan Bonds: Political Reputations and Legislative Accountability. New York: Cambridge University Press.

Hacker, Jacob S. and Paul Pierson. 2005. Off Center: The Republican Revolution and the Erosion of American Democracy. New Haven, CT: Yale University Press.

Heberlig, Eric, Marc Hetherington, and Bruce Larson. 2006. "The Price of Leadership: Campaign Money and the Polarization of Congressional Parties." Journal of Politics 68(4): 992-1005.

Hetherington, Marc J. 2001. "Resurgent Mass Partisanship: The Role of Elite Polarization." American Political Science Review 95(3): 619-631.

Hirano, Shigeo, James M. Snyder, Jr., Stephen Ansolabehere, and John Mark Hansen. 2010. Primary Elections and Partisan Polarization in Congress. Quarterly Journal of Political Science 5: 169-191.

Klarner, Carl. 2013. "State Partisan Balance Data, 1937 - 2011." http://hdl.handle.net/1902.1/20403 IQSS Dataverse Network [Distributor] V1 [Version]

Jacobson, Gary C. 2004. The Politics of Congressional Elections. New York: Longman.

Jacobson, Gary C. and Samuel Kernell. 1983. Strategy and Choice in Congressional Elections, $2^{\text {nd }}$ ed. New Haven, CT: Yale University Press. 
Jessee, Stephen and Neil Malhotra. 2010. "Are Congressional Leaders Middlepersons or Extremists? Yes.” Legislative Studies Quarterly 35(3): 361-392.

Layman, Geoffrey C. and Thomas M. Carsey. 2002. "Party Polarization and 'Conflict Extension' in the American Electorate." American Journal of Political Science 46(4): 786-802.

Layman, Geoffrey C., Thomas M. Carsey, John C. Green, Richard Herrera, and Rosalyn Cooperman. 2010. "Activists and Conflict Extension in American Party Politics." American Political Science Review 104(2): 324-346.

Levendusky, Matthew. 2009. The Partisan Sort: How Liberals Became Democrats and Conservatives Became Republicans. Chicago: University of Chicago Press.

Mann, Thomas E. and Norman J. Ornstein. 2012. It's Even Worse Than It Looks: How the American Constitutional System Collided With the New Politics of Extremism. New York: Basic Books.

Maestas, Cherie D., Sarah A. Fulton, L. Sandy Maisel, and Walter J. Stone. 2006. "When to Risk It? Institutions, Ambitions, and the Decision to Run for the U.S. House." American Political Science Review 100(2): 195-208.

Mayhew, David R. 1974. Congress: The Electoral Connection. New Haven: Yale University Press.

McCarty, Nolan, Keith T. Poole, and Howard Rosenthal. 2006. Polarized America: The Dance of Ideology and Unequal Riches. Cambridge: Massachusetts Institute of Technology Press.

McCarty, Nolan, Keith T. Poole, and Howard Rosenthal. 2009. "Does Gerrymandering Cause Polarization?” American Journal of Political Science 53(3): 666-680.

McGhee, Eric, Seth Masket, Boris Shor, Steve Rogers, and Nolan McCarty. 2013. "A Primary Cause of Partisanship? Nomination Systems and Legislator Ideology." American Journal of Political Science 00(0): 1-15.

McGhee, Eric and Kathryn Pearson. 2011. "Candidates and Parties in Congressional Elections: Revisiting Candidate-Centered Conclusions in a Partisan Era." In Facing the Challenge of Democracy: Explorations in the Analysis of Public Opinion and Political Participation, eds. Paul M. Sniderman and Benjamin Highton. Princeton, NJ: Princeton University Press.

National Conference of State Legislatures (NCSL). 2013. "Number of State Legislators and Length of Terms (In Years)." Accessed at http://www.ncsl.org/research/about-state legislatures/number-of-legislators-and-length-of-terms.aspx. 
Poole, Keith T. and Howard Rosenthal. 2007. Ideology and Congress. New Brunswick, NJ: Transaction Publishers.

Roberts, Jason M. and Steven S. Smith. 2003. "Procedural Contexts, Party Strategy, and Conditional Party Voting in the U.S. House of Representatives, 1971-2000." American Journal of Political Science 47(2): 305-317.

Rohde, David W. 1979. "Risk-Bearing and Progressive Ambition: The Case of Members of the United States House of Representatives." American Journal of Political Science 23(1): $1-26$.

Rohde, David W. 1991. Parties and Leaders in the Postreform House. Chicago: University of Chicago Press.

Sanbonmatsu, Kira. 2006. Where Women Run: Gender and Party in the American States. Ann Arbor: University of Michigan Press.

Schlesinger, Joseph A. 1966. Ambition and Politics: Political Careers in the United States. Chicago: Rand McNally.

Sides, John and Lynn Vavreck. 2013. "On the Representativeness of Primary Electorates." Paper presented at the conference "Political Representation: Fifty Years after Miller and Stokes," Vanderbilt University, March 2013.

Sinclair, Barbara. 2006. Party Wars: Polarization and the Politics of National Policy Making. Norman, OK: University of Oklahoma Press.

Skocpol, Theda and Vanessa Williamson. 2012. The Tea Party and the Remaking of Republican Conservatism. New York: Oxford University Press.

Sniderman, Paul M. and Edward H. Stiglitz. 2012. The Reputational Premium: A Theory of Party Identification and Policy Reasoning. Princeton, NJ: Princeton University Press.

Snyder, James M. and Michael M. Ting. 2002. "An Informational Rationale for Political Parties.” American Journal of Political Science 46(1): 90-110.

Squire, Peverill. 2007. "Measuring State Legislative Professionalization: The Squire Index Revisited." State Politics \& Policy Quarterly 7(2): 211-227.

Stone, Walter J., and L. Sandy Maisel. 2003. "The Not-So-Simple Calculus of Winning: Potential U.S. House Candidates' Nomination and General Election Chances." Journal of Politics 65(4): 951-977.

Stone, Walter J., L. Sandy Maisel, and Cherie D. Maestas. 2004. "Quality Counts: Extending the Strategic Politician Model of Incumbent Deterrence.” American Journal of Political Science 48(3): 479-495. 
Stonecash, Jeffrey M., Mark D. Brewer, and Mark D. Mariani. 2003. Diverging Parties: Social Change, Realignment, and Party Polarization. Boulder, CO: Westview Press.

Tausanovitch, Chris and Christopher Warshaw. 2013. "Measuring Constituent Policy Preferences in Congress, State Legislatures, and Cities." Journal of Politics 75(2): $330-42$.

Theriault, Sean M. 2006. "Party Polarization in the U.S. Congress: Member Replacement and Member Adaptation." Party Politics 12(4): 483-503.

Theriault, Sean M. 2008. Party Polarization in Congress. New York: Cambridge University Press. 


\section{Online Appendix}

Supplementary Appendix A: Summary Statistics (Republican State Legislators)

\begin{tabular}{|l|c|c|c|c|}
\hline & Mean & Median & SD & Range \\
\hline Table 1 & & & & \\
\hline DV: Chance of Winning & 0.50 & 0.50 & 0.32 & {$[0.01,0.99]$} \\
\hline DV: Value of House Seat & 0.07 & 0 & 2.94 & {$[-10,9]$} \\
\hline Self-Reported Ideology & 2.35 & 2 & 0.80 & {$[1,5]$} \\
\hline District Partisanship & 0.60 & 1 & 0.49 & {$[0,1]$} \\
\hline Raise Money & 5.15 & 5 & 1.24 & {$[1,7]$} \\
\hline Contacted by Party & 0.23 & 0 & 0.62 & {$[0,4]$} \\
\hline Terms in State Legislature & 2.37 & 2 & 1.05 & {$[1,4]$} \\
\hline Professional Legislature & 2.71 & 3 & 1.40 & {$[1,5]$} \\
\hline Incumbent Strength & 5.82 & 6 & 1.15 & {$[1,7]$} \\
\hline Support from Groups & 5.21 & 5 & 1.26 & {$[1,7]$} \\
\hline Female & 0.14 & 0 & 0.34 & {$[0,1]$} \\
\hline Age & 3.91 & 4 & 1.33 & {$[1,6]$} \\
\hline & & & & \\
Table 2 & & & & {$[0,1]$} \\
\hline DV: Run for Congress & 0.02 & 0 & 0.14 & {$[0.96,1.47]$} \\
\hline State Legislator Ideology (Moderate) & -0.68 & -0.72 & 0.37 & {$[-1.96,1]$} \\
\hline Incumbent Running in District & 0.89 & 1 & 0.32 & {$[0,1]$} \\
\hline Congressional District Ideology & 0.11 & 0.15 & 0.20 & {$[-0.89,0.49]$} \\
\hline Receipts Raised as State Legislator & 10.78 & 10.81 & 1.32 & {$[3.26,15.04]$} \\
\hline Times Run for State Legislature & 3.37 & 3 & 1.60 & {$[1,10]$} \\
\hline Female & 0.17 & 0 & 0.38 & {$[0,1]$} \\
\hline In Professionalized State Legislature & 0.19 & 0.17 & 0.11 & {$[0.03,0.63]$} \\
\hline In State Legislature with Term Limits & 0.25 & 0 & 0.43 & {$[0,1]$} \\
\hline Democratic Control of State Legislature & 0.42 & 0.38 & 0.41 & {$[0,1]$} \\
\hline Extreme Ideologue & 0.01 & 0 & 0.07 & {$[0,1]$} \\
\hline Note: In Tale an & & 0.43 & \\
\hline
\end{tabular}

Note: In Table 1, all non-dummy predictor variables were standardized to have a mean of zero and a standard deviation of one. 
Supplementary Appendix A: Summary Statistics (Democratic State Legislators)

\begin{tabular}{|l|c|c|c|c|}
\hline & Mean & Median & SD & Range \\
\hline Table 1 & & & & \\
\hline DV: Chance of Winning & 0.51 & 0.50 & 0.30 & {$[0.01,0.99]$} \\
\hline DV: Value of House Seat & -0.90 & -1 & 3.15 & {$[-12,9]$} \\
\hline Self-Reported Ideology & 3.56 & 4 & 1.34 & {$[1,6]$} \\
\hline District Partisanship & 0.64 & 1 & 0.48 & {$[0,1]$} \\
\hline Raise Money & 4.94 & 5 & 1.35 & {$[1,7]$} \\
\hline Contacted by Party & 0.32 & 0 & 0.74 & {$[0,4]$} \\
\hline Terms in State Legislature & 2.55 & 3 & 1.17 & {$[1,4]$} \\
\hline Professional Legislature & 2.60 & 2 & 1.34 & {$[1,5]$} \\
\hline Incumbent Strength & 5.60 & 6 & 1.32 & {$[1,7]$} \\
\hline Support from Groups & 5.17 & 5 & 1.38 & {$[1,7]$} \\
\hline Female & 0.29 & 0 & 0.45 & {$[0,1]$} \\
\hline Age & 3.70 & 4 & 1.21 & {$[1,6]$} \\
\hline & & & & \\
Table 2 & & & & \\
\hline DV: Run for Congress & 0.01 & 0 & 0.11 & {$[0,1]$} \\
\hline State Legislator Ideology (Moderate) & -0.43 & -0.48 & 0.53 & {$[-1.91,1.94]$} \\
\hline Incumbent Running in District & 0.90 & 1 & 0.30 & {$[0,1]$} \\
\hline Congressional District Ideology & -0.09 & -0.07 & 0.29 & {$[-1.09,0.49]$} \\
\hline Receipts Raised as State Legislator & 10.78 & 10.81 & 1.28 & {$[5.23,15.45]$} \\
\hline Times Run for State Legislature & 3.44 & 3 & 1.67 & {$[1,11]$} \\
\hline Female & 0.28 & 0 & 0.45 & {$[0,1]$} \\
\hline In Professionalized State Legislature & 0.21 & 0.17 & 0.12 & {$[0.03,0.63]$} \\
\hline In State Legislature with Term Limits & 0.21 & 0 & 0.41 & {$[0,1]$} \\
\hline Democratic Control of State Legislature & 0.63 & 0.75 & 0.40 & {$[0,1]$} \\
\hline Extreme Ideologue & 0.01 & 0 & 0.11 & {$[0,1]$} \\
\hline No In Ta & & 0.17 & \\
\hline
\end{tabular}

Note: In Table 1, all non-dummy predictor variables were standardized to have a mean of zero and a standard deviation of one. 


\section{Supplementary Appendix B: Alternative Specification of Legislator Ideology (Table 1)}

The Determinants of State Legislators' Perceived Ability to Achieve their Electoral and Policy Goals, By Party (With Policy Positions)

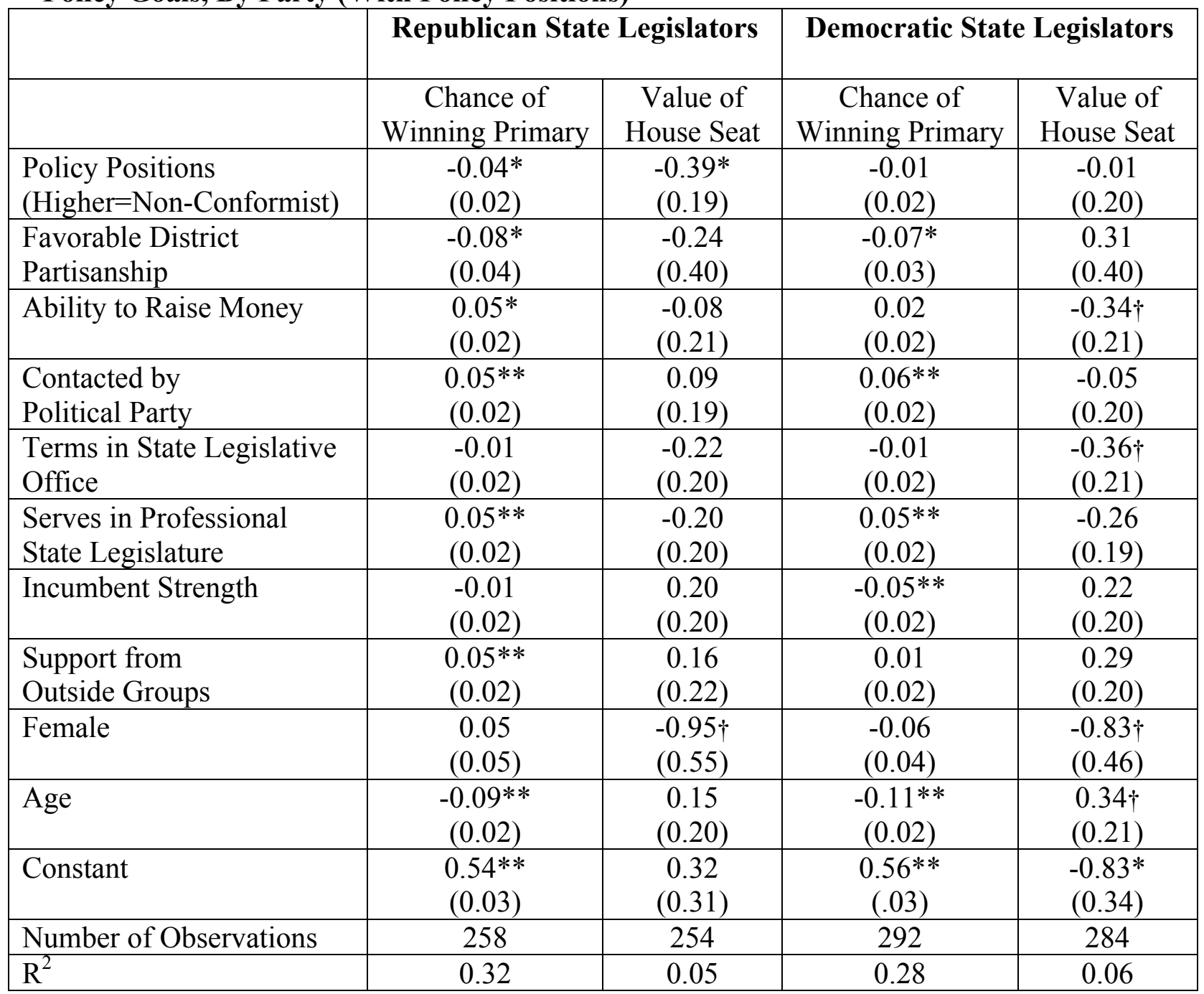

Source: 1998 Wave of the Candidate Emergence Study (Stone and Maisel 2003; Stone et al. 2004; Maestas et al. 2006). Note: Entries are OLS regression coefficients with standard errors in parentheses.

$* *=p<0.01, *=p<0.05, \dagger=p<0.10$. 
Supplementary Appendix C: Full Sample of State Legislators (Table 1)

The Determinants of State Legislators' Perceived Ability to Achieve their Electoral and Policy Goals, Full Sample (With Self-Reported Ideology and Policy Positions)

\begin{tabular}{|c|c|c|c|c|}
\hline & \multicolumn{2}{|c|}{ All State Legislators } & \multicolumn{2}{|c|}{ All State Legislators } \\
\hline & $\begin{array}{c}\text { Chance of } \\
\text { Winning Primary }\end{array}$ & $\begin{array}{l}\text { Value of } \\
\text { House Seat }\end{array}$ & $\begin{array}{c}\text { Chance of } \\
\text { Winning Primary }\end{array}$ & $\begin{array}{c}\text { Value of } \\
\text { House Seat }\end{array}$ \\
\hline $\begin{array}{l}\text { Self-Reported Ideology } \\
\text { (Higher=Centrist) }\end{array}$ & $\begin{array}{l}-0.01 \\
(0.01)\end{array}$ & $\begin{array}{l}-0.26 \dagger \\
(0.13)\end{array}$ & - & - \\
\hline $\begin{array}{l}\text { Policy Positions } \\
\text { (Higher=Non-Conformist) }\end{array}$ & - & - & $\begin{array}{l}-0.02 \\
(0.01) \\
\end{array}$ & $\begin{array}{l}-0.26^{*} \\
(0.13)\end{array}$ \\
\hline $\begin{array}{l}\text { Favorable District } \\
\text { Partisanship }\end{array}$ & $\begin{array}{l}-0.06^{*} \\
(0.02)\end{array}$ & $\begin{array}{l}-0.03 \\
(0.27)\end{array}$ & $\begin{array}{c}-0.06^{* *} \\
(0.03)\end{array}$ & $\begin{array}{c}0.05 \\
(0.28)\end{array}$ \\
\hline Ability to Raise Money & $\begin{array}{c}0.04^{* *} \\
(0.01)\end{array}$ & $\begin{array}{l}-0.22 \\
(0.14)\end{array}$ & $\begin{array}{c}0.04 * * \\
(0.01)\end{array}$ & $\begin{array}{l}-0.19 \\
(0.15)\end{array}$ \\
\hline $\begin{array}{l}\text { Contacted by } \\
\text { Political Party }\end{array}$ & $\begin{array}{l}0.06^{* *} \\
(0.01)\end{array}$ & $\begin{array}{c}0.00 \\
(0.13)\end{array}$ & $\begin{array}{l}0.05^{* *} \\
(0.01)\end{array}$ & $\begin{array}{l}-0.01 \\
(0.14)\end{array}$ \\
\hline $\begin{array}{l}\text { Terms in State Legislative } \\
\text { Office }\end{array}$ & $\begin{array}{l}-0.01 \\
(0.01)\end{array}$ & $\begin{array}{l}-0.29^{*} \\
(0.14)\end{array}$ & $\begin{array}{l}-0.01 \\
(0.01)\end{array}$ & $\begin{array}{l}-0.35^{*} \\
(0.14)\end{array}$ \\
\hline $\begin{array}{l}\text { Serves in Professional } \\
\text { Legislature }\end{array}$ & $\begin{array}{l}0.05^{* *} \\
(0.01)\end{array}$ & $\begin{array}{l}-0.23 \dagger \\
(0.13)\end{array}$ & $\begin{array}{l}0.05^{* *} \\
(0.01)\end{array}$ & $\begin{array}{l}-0.22 \\
(0.14)\end{array}$ \\
\hline Incumbent Strength & $\begin{array}{c}-0.03 * * \\
(0.01)\end{array}$ & $\begin{array}{l}0.30^{*} \\
(0.13)\end{array}$ & $\begin{array}{l}-0.03 * \\
(0.01)\end{array}$ & $\begin{array}{l}0.24 \dagger \\
(0.14)\end{array}$ \\
\hline $\begin{array}{l}\text { Support from } \\
\text { Outside Groups }\end{array}$ & $\begin{array}{l}0.02 \dagger \\
(0.01)\end{array}$ & $\begin{array}{c}0.19 \\
(0.14)\end{array}$ & $\begin{array}{l}0.03^{*} \\
(0.01)\end{array}$ & $\begin{array}{l}0.24 \dagger \\
(0.14)\end{array}$ \\
\hline Woman & $\begin{array}{l}-0.02 \\
(0.03)\end{array}$ & $\begin{array}{c}-1.00^{* *} \\
(0.32)\end{array}$ & $\begin{array}{l}-0.03 \\
(0.03)\end{array}$ & $\begin{array}{c}-1.10^{* * *} \\
(0.33)\end{array}$ \\
\hline Age & $\begin{array}{c}-0.10^{* *} \\
(0.01)\end{array}$ & $\begin{array}{l}0.27 \dagger \\
(0.14)\end{array}$ & $\begin{array}{c}-0.10^{* *} \\
(0.01)\end{array}$ & $\begin{array}{l}0.28 \dagger \\
(0.14)\end{array}$ \\
\hline Constant & $\begin{array}{l}0.55^{* *} \\
(0.02)\end{array}$ & $\begin{array}{l}-0.22 \\
(0.22)\end{array}$ & $\begin{array}{l}0.55^{* *} \\
(0.02)\end{array}$ & $\begin{array}{l}-0.21 \\
(0.23)\end{array}$ \\
\hline Number of Observations & 569 & 569 & 538 & 538 \\
\hline $\mathrm{R}^{2}$ & 0.27 & 0.06 & 0.26 & 0.06 \\
\hline
\end{tabular}

Source: 1998 Wave of the Candidate Emergence Study (Stone and Maisel 2003; Stone et al. 2004; Maestas et al. 2006). Note: Entries are OLS regression coefficients with standard errors in parentheses.

$* *=\mathrm{p}<0.01, *=\mathrm{p}<0.05, \dagger=\mathrm{p}<0.10$. 


\section{Supplementary Appendix D: Distributions of State Legislator Ideology, By Party}

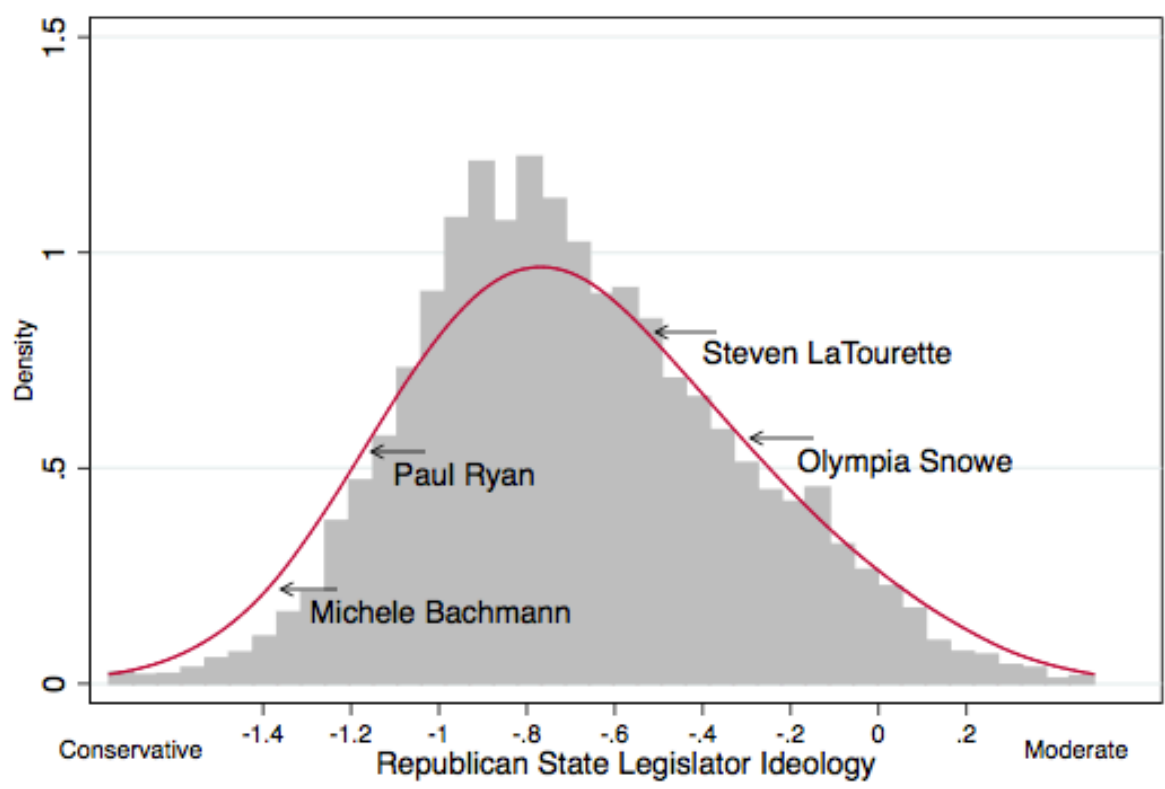

Note: The graph shows the ideological distribution of Republican state legislators used in Table 2. The arrows refer to the relative ideological placement of various former and current members of Congress.

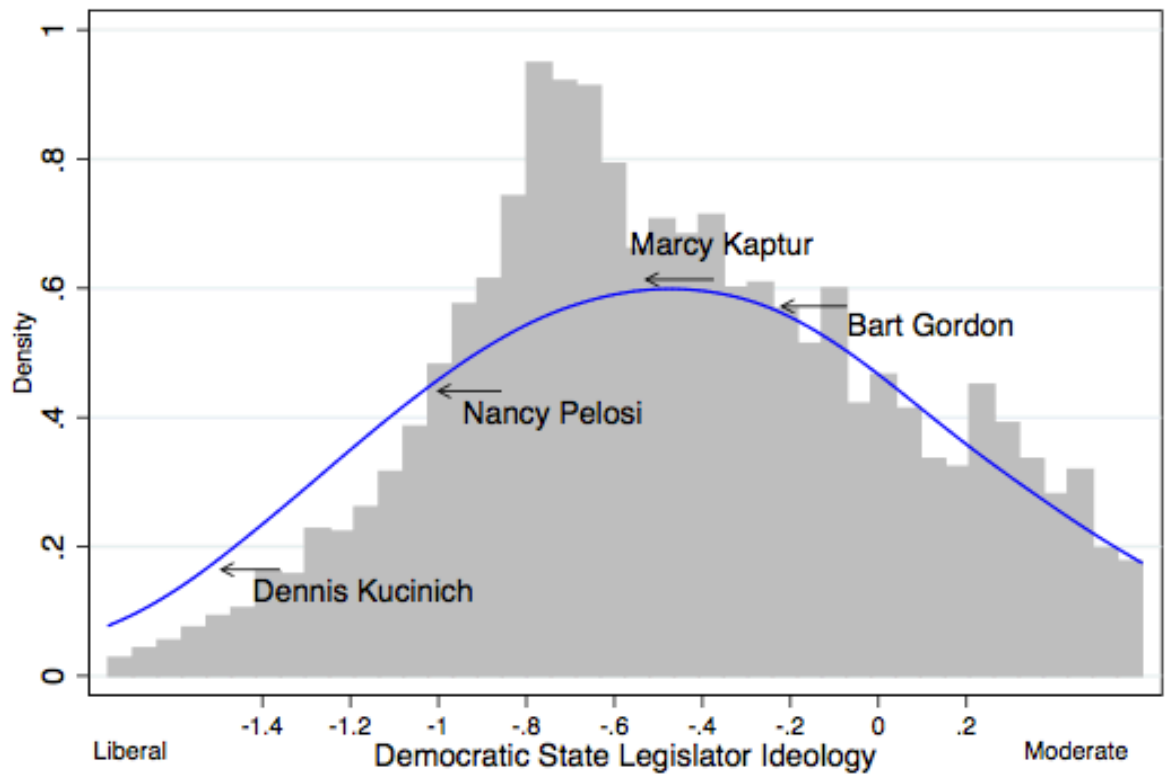

Note: The graph shows the ideological distribution of Democratic state legislators used in Table 2. The arrows refer to the relative ideological placement of various former and current members of Congress. 


\section{Supplementary Appendix E: Alternative Specifications of Party Fit (Table 2)}

The Determinants of Running for Congress, By Party (2000-2010) (With Absolute Distance from Party Median in Congress and Relative Closeness to Own Party in Congress)

\begin{tabular}{|c|c|c|c|c|}
\hline & $\begin{array}{l}\text { Republican } \\
\text { Legislators }\end{array}$ & $\begin{array}{l}\text { Democratic } \\
\text { Legislators }\end{array}$ & $\begin{array}{l}\text { Republican } \\
\text { Legislators }\end{array}$ & $\begin{array}{l}\text { Democratic } \\
\text { Legislators }\end{array}$ \\
\hline $\begin{array}{l}\text { Distance between State } \\
\text { Legislator and Party } \\
\text { Median in Congress } \\
\text { (Higher=Distant) }\end{array}$ & $\begin{array}{c}-1.79 * * \\
(0.32)\end{array}$ & $\begin{array}{c}-1.14^{* *} \\
(0.24)\end{array}$ & 0 & 0 \\
\hline $\begin{array}{l}\text { Relative Closeness to } \\
\text { Own Party in Congress } \\
\text { (Higher=Closer) }\end{array}$ & - & - & $\begin{array}{l}1.74^{* *} \\
(0.20)\end{array}$ & $\begin{array}{l}1.33 * * \\
(0.18)\end{array}$ \\
\hline $\begin{array}{l}\text { Incumbent Running in } \\
\text { Congressional District }\end{array}$ & $\begin{array}{c}-2.31 * * \\
(0.13)\end{array}$ & $\begin{array}{c}-2.41 * * \\
(0.16)\end{array}$ & $\begin{array}{l}-2.34 * * \\
(0.13)\end{array}$ & $\begin{array}{l}-2.38^{* *} \\
(0.16)\end{array}$ \\
\hline $\begin{array}{l}\text { Ideology of } \\
\text { Congressional District }\end{array}$ & $\begin{array}{l}-1.14^{* *} \\
(0.35)\end{array}$ & $\begin{array}{c}0.14 \\
(0.30)\end{array}$ & $\begin{array}{c}-1.80^{* *} \\
(0.32)\end{array}$ & $\begin{array}{c}0.62 \\
(0.33)\end{array}$ \\
\hline $\begin{array}{l}\text { Log of Receipts Raised } \\
\text { as State Legislator }\end{array}$ & $\begin{array}{l}0.29^{* *} \\
(0.05)\end{array}$ & $\begin{array}{l}0.34^{* *} \\
(0.06)\end{array}$ & $\begin{array}{l}0.37^{* *} \\
(0.05)\end{array}$ & $\begin{array}{l}0.43^{* *} \\
(0.06)\end{array}$ \\
\hline $\begin{array}{l}\text { Number of Times Run } \\
\text { for State Legislature }\end{array}$ & $\begin{array}{l}0.26^{* *} \\
(0.04)\end{array}$ & $\begin{array}{l}0.23^{* *} \\
(0.05)\end{array}$ & $\begin{array}{l}0.31^{* *} \\
(0.04)\end{array}$ & $\begin{array}{l}0.25^{* *} \\
(0.05)\end{array}$ \\
\hline Woman & $\begin{array}{l}-0.06 \\
(0.17)\end{array}$ & $\begin{array}{l}-0.05 \\
(0.16)\end{array}$ & $\begin{array}{l}-0.10 \\
(0.17)\end{array}$ & $\begin{array}{l}-0.24 \\
(0.16)\end{array}$ \\
\hline $\begin{array}{l}\text { In Professionalized } \\
\text { State Legislature }\end{array}$ & $\begin{array}{l}1.54^{* *} \\
(0.57)\end{array}$ & $\begin{array}{l}1.28 \\
(0.71)\end{array}$ & $\begin{array}{l}1.90^{* *} \\
(0.57)\end{array}$ & $\begin{array}{c}0.72 \\
(0.71)\end{array}$ \\
\hline $\begin{array}{l}\text { In State Legislature } \\
\text { with Term Limits }\end{array}$ & $\begin{array}{l}0.62 * * \\
(0.14)\end{array}$ & $\begin{array}{l}1.05^{* *} \\
(0.17)\end{array}$ & $\begin{array}{l}0.65^{* *} \\
(0.14)\end{array}$ & $\begin{array}{l}0.97 * * \\
(0.17)\end{array}$ \\
\hline $\begin{array}{l}\text { Democratic Control of } \\
\text { State Legislature }\end{array}$ & $\begin{array}{l}0.43^{* *} \\
(0.17)\end{array}$ & $\begin{array}{l}-0.05 \\
(0.20)\end{array}$ & $\begin{array}{l}0.68^{* *} \\
(0.17)\end{array}$ & $\begin{array}{l}-0.19 \\
(0.22)\end{array}$ \\
\hline Constant & $\begin{array}{l}-6.49^{* *} \\
(0.64)\end{array}$ & $\begin{array}{c}-7.47^{* *} \\
(0.73)\end{array}$ & $\begin{array}{l}-10.43^{* *} \\
(0.78)\end{array}$ & $\begin{array}{l}-10.32^{* *} \\
(0.76)\end{array}$ \\
\hline Number of Observations & 14,459 & 16,571 & 14,459 & 16,571 \\
\hline Log-Likelihood & -1183.09 & -926.33 & -1139.26 & -888.29 \\
\hline
\end{tabular}

Source: State legislator estimates and party estimates are from Bonica (2013b).

Note: Entries are logistic regression coefficients with robust standard errors clustered by individual in parentheses.

The dependent variable is coded 1 if the incumbent state legislator ran for Congress and 0 if the incumbent state legislator instead ran for the state legislature. $* *=\mathrm{p}<0.01, *=\mathrm{p}<0.05$. 


\section{Supplementary Appendix F: State Legislators who are Extreme Ideological Outliers, By Party}

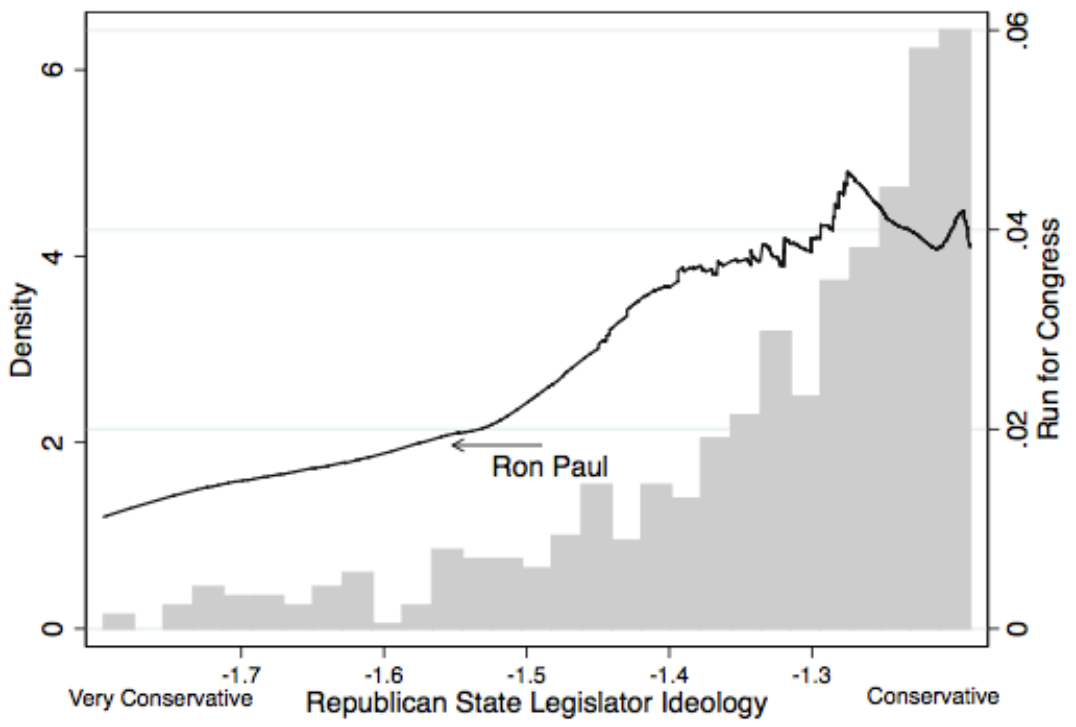

Note: The graph shows the probability of running for Congress among Republican state legislators who are ideological outliers (as conservative as Ron Paul, for example). We can see that the probability of running also decreases among very conservative state legislators, which aligns with the argument here. The state legislators in this figure comprise $6 \%$ of the Republican sample used in the analysis in Table 2.

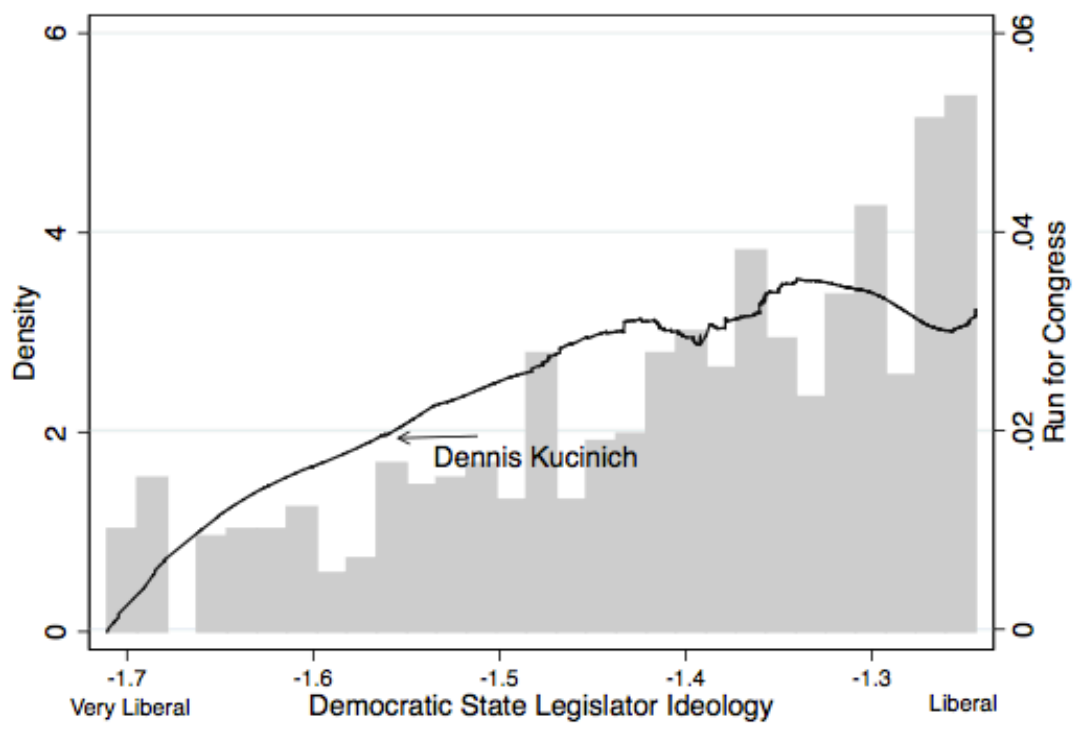

Note: The graph shows the probability of running for Congress among Democratic state legislators who are ideological outliers (as liberal as Dennis Kucinich, for example). We can see that the probability of running also decreases among very liberal state legislators, which aligns with the argument here. The state legislators in this figure comprise $5 \%$ of the Democratic sample used in the analysis in Table 2. 